International Review of Research in Open and Distributed Learning Volume 16, Number 4

October - 2015

\title{
Appreciative Leadership: Supporting Education Innovation
}

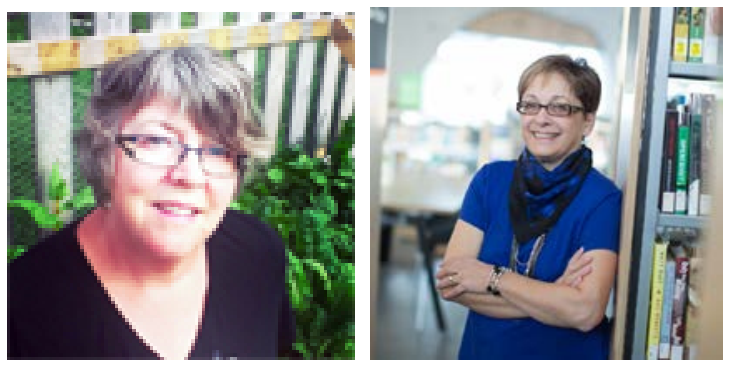

Tracy Orr and Marti Cleveland-Innes

Athabasca University

\begin{abstract}
Appreciative Leadership is unique among leadership theories both past and present. This uniqueness includes its strength-based practice, search for the positive in people and organizations, and the role this plays in organizational innovation and transformation. What follows is a summary of Appreciative Inquiry and the five main principles on which it is based. We then discuss Appreciative Leadership in terms of its place among leadership theories in general. Finally we look at the potential of Appreciative Leadership inK-12 contexts.
\end{abstract}

Keywords: Leadership, Appreciative Inquiry, Education.

\section{Appreciative Inquiry}

Appreciative Leadership is grounded in the field of Appreciative Inquiry (AI) defined by Cooperrider \& Whitney (2005) as "the co-evolutionary search for the best in people, their organizations, and the world around them. It involves systematic discovery of what gives a system 
Iife' when it is most effective and capable in economic, ecological, and human terms. AI involves the art and practice of asking questions that strengthen a system's capacity to heighten positive potential" (p.17). Appreciative inquiry unapologetically and deliberately focuses on the positive in organizations in ways that unleash creativity and new possibilities for both the organization and its employees and, in doing so, sets itself apart from other leadership and organizational change theories.

What does it mean to approach leadership and organizational change from a stance of Appreciative Inquiry? To begin with, AI taps into what is termed the positive change core of the organization. AI "assumes that every living system has many untapped and rich and inspiring accounts of the positive" (p.18). The positive change core of the organization is seen to be a vast and untapped resource in organizations. It is the energy of this core of positive stories and accounts of mountain top moments and most memorable achievements collected from the people in organizations that fuel the change in the organization.

Appreciative Inquiry is based on five main principles that reflect its theoretical base and views on change. These principles are the Constructivist Principle, the Principle of Simultaneity, the Poetic Principle, the Anticipatory Principle, and the Positive Principle. We outline each principle below and identify the link between these principles and how Appreciative Leadership begins to unfold from these principles.

The Constructivist Principle acknowledges that organizations are living, human constructions. To be a leader, according to this principle, is to know and understand an organization as a human construction, as ever changing, and is 'how' one knows an organization.

The Principle of Simultaneity sees inquiry as intervention. Rather than one following the other, the questions we ask and the changes we make are not separate moments but are considered to be simultaneous. AI sees change as embedded in the types of questions we ask. What results from our questions becomes that which shapes our future. Leaders, then, guide which questions are asked, what changes are made, and encourages movement toward a new future.

The Poetic Principle reflects the metaphor that an organization is much like an emerging book. However, this story is constantly being co-authored and re-interpreted. All topics, like all human experience, are open to exploration and re-consideration. There is no need therefore to rehash and relive the same reality over and over again. We can ask new questions. The Appreciative Leader makes the story, and its unfolding, explicit. Each participating author of the story in acknowledged and validated for contributing, wherever the story may go.

The Anticipatory Principle is based on the observation that human beings are forever looking to and anticipating the future. What we imagine about the future and our conversations about that future guides present behaviour. Inquiry, the kinds of questions we ask, helps to shape that 
anticipatory reality. An Appreciative Leader encourages positive inquiry and an imagery which leads to new, even multiple, future realities. This plays out as a communal forum which involves all its participants.

The final principle of AI, The Positive Principle, is both clear and profound. Appreciative Inquiry is ultimately relational. Positive affect, caring, shared meaning, and purpose fuel change efforts. The more positive the central driving question, the more momentum for change is created and the more lasting the change experienced. Accordingly, leaders monitor and manage this frame of reference.

Research into Appreciative Inquiry has determined the veracity of its claims in reference to organizational transformation. In a meta-case analysis answering the question, "When is Appreciative Inquiry transformational?" Bushe and Kassam (2005) investigated 20 cases of companies using AI to change their social and organizational environments. The most powerful and transformational changes occurred in the AI cases where: 1) there was a focus on changing how people think rather than on what people do and; 2) where there was support for and freedom for staff to innovate and organize themselves in order to follow new ideas. Bushe and Kassam also caution that using AI techniques with conventional organizational change processes, which "rely on elaborate and formalized implementation strategies, parallel structures, and project management techniques" (p. 176) may yield fewer transformational outcomes.

Appreciative inquiry has been critiqued by a number of scholars, many of whom use AI themselves. One of the most common critiques involves the initial focus of AI on positive stories and experiences. Focusing exclusively on positive experiences may result in invalidating the negative experiences of staff and result in missed opportunities to address these experiences and the potentially helpful conversations that might arise out them (Bushe, 2012). In other research (Bushe, 2010), AI is suggested to result in transformational change only if it addresses problems of real concern of staff. Identifying the negative may not be generational but it may still have a place in the overall AI and leadership process.

\section{Appreciative Leadership}

The role of an appreciative leader is to be a catalyst of change and to look for and nurture the best in others (Whitney, Trosten-Bloom, \& Rader, 2010; Cooperrider \& Whitney, 2005). An Appreciative Leader is a strength-based leader. Leaders are considered to be role models of appreciative inquiry in their relationships with others and participate along with other staff and colleagues in the inquiry process. In a sense, the leader is less important than the questions she or he asks, the discourse these questions create, and the ongoing quest of seeing the positive potential in both the staff and organization. Leadership theories such as the Great Man Theory, Trait Theory, Behaviour Theory, and Transformational Theory rely on the characteristics and behaviours of the leader and elevate the leader in a way that would be counter - productive in an Appreciative Inquiry environment. Contingency Theory matches the characteristics of the leader 
with situational variables and therefore also misses the mark. What is necessary, and lacking in these other perspective on leadership, is the view of a positive core waiting to be discovered in all organizations.

Transactional theories of leadership and Leader Membership Exchange (LMX) theories focus on the relationship of leader and member (Avolio, Walumba, \& Weber, 2009). Both theories originate in behavioural theory although LMX theory has moved beyond this theory to focus on different aspects of leader-follower dyads. Appreciative Inquiry moves beyond this behavioural analysis and discussion of leader/ follower dynamics to a broader view of organizational member participation as a co-constructor of present and future possibilities.

Appreciative Leaders work towards a flatter hierarchical structure such that all staff participate in answering the central positive questions at hand and are empowered to innovate and create what is needed to move the organization forward. Appreciative Leaders trust the people they work with enough to step back and allow their staff, co-constructors of the organizational future vision, to get to work. This is a very different leadership role and although models of distributed and shared leadership may come closer in reflecting a flatter and more shared leadership structure, the key to Appreciative Leadership is the leader's place within an appreciative process which sets this leadership theory apart from many others.

\section{Appreciative Leadership in a K-12 World}

Schools and school divisions are based on hierarchical models of leadership where organizational direction follows an organizational chart of Superintendent, assistant superintendents, leaders of departments such as Financial officer, Student Service Director, and beneath them another layer exists of Principals, Vice-principals, teachers, educational assistants, administrative assistants, caretakers, and bus drivers, often in that order of organizational influence.

Schools and school divisions, like many other organizations, often operate from a deficit or problem-centred model. Whether consultants are engaged or groups of school administrators are employed, the method of operation is often to identify a problem and come up with solutions. Problem-based approaches focus on what is not wanted rather than on what is desired for students. Cooperrider (2001) also identifies an over-reliance on problem-based models in organizations. From a school perspective, leadership becomes focused on past failures and finding ways of identifying, documenting and intervening in these failures in order to improve performance. One of the most typical characterizations by teachers of addressing problems in the $\mathrm{K}-12$ world is 're-inventing the wheel' or, in other words, returning to status quo.

Daly and Chrispeels (2005) call for a shift from both deficit and problem-based orientations in schools to more strength-based models and discuss how initially problem-based inquiry can devolve in deficit-based thinking. Dialogues in schools become essentially fault finding and threatening which leads problem-solving efforts to remain at superficial levels and be more likely 
to focus on external factors (like families, student characteristics) rather than pedagogy or classroom factors (Cuban \& Usdan, 2003). Appreciative leadership supports innovation throughout the organization by rejecting problem-based and deficit models in favour of freeing staff to generate new and innovative solutions.

There are also vast numbers of students whose experience in K-12 schools could inform the appreciative process in ways that are really unfathomable. From an appreciative leadership perspective, the potential for K-12 contexts to identify strengths and co-construct new realities is, essentially, unlimited. Waters and White (2015), for example, outline a systemic change plan using Appreciative Inquiry methods. They offer a detailed review of a "case study (which) provides one example that supports the growing number of calls in the field of educational leadership for schools to adopt more appreciative change approaches (Calabrese, 2006; Calabrese, Hummel, \& San Martin, 2007; Calabrese, San Martin, Glasgow, \& Friesen 2008)” (p. 30)..

In conclusion, Appreciative Leadership, and Appreciative Inquiry as a process, holds out hope by identifying the strengths and positive nature of the organization and its staff and by introducing democratic leadership and processes that work to flatten the hierarchical structure through full participation of its members. As Bushe and Kassam (2005) observed, we need to change the way we think before we change the way we behave. The K-12 world is in need of Appreciative Leaders and Leadership to help restore the morale of its members and liberate their considerable strengths and innovative capacities in the service of future generations.

\section{References}

Avolio, B., Walumbwa, F., \&Weber, T. (2009). Leadership: Current theories, research and future directions. Management Department Faculty Publications, 37.

Bushe, G. (2012). Foundations of appreciative inquiry: History, Criticism and Potential. AI Practitioner, 14(1), 8-19.

Bushe, G. (2011). Appreciative inquiry: Theory and critique. In Boje, D., Burnes, B. and Hassard, J . (Eds.), The Routledge Companion To Organizational Change (pp. 87-103). Oxford, UK: Routledge.

Bushe, G., \& Kassam, A. (2005). When is appreciative inquiry transformational? A meta-case analysis. The J ournal of Applied Behavioural Science, 41(2), 161-181. 
Cooperrider, D., \& Srivastva, S. (1987). Appreciative inquiry in organizational life. In Woodman R. \& Pasmore, W. (eds.) Research In Organizational Change And Development, 1(129169). Stamford, CT: JAI Press.

Calabrese, R. (2006). Building social capital through the use of an appreciative inquiry: Theoretical perspective in a school and university partnership. International J ournal of Educational Management, 20(3), 173-82. http://dx.doi.org/ 10.1108/09513540610654146

Calabrese, R., Hummel, C., \& San Martin, T. (2007). Learning to appreciate at-risk students: Challenging the beliefs and attitudes of teachers and administrators. International J ournal of Educational Management, 21(4), 275-291. http:// dx.doi.org/ 10.1108/09513540710749500

Calabrese, R., San Martin, T., Glasgow, J ., \&Friesen, S. (2008). The power of an appreciative inquiry 4-D cycle in a non-AYP middle school: Positive direction for eighth-grade teachers. J ournal of Research for Educational Leaders, 4(2), 17-42.

Cooperrider, D., \& Whitney, D. (2005). Appreciative inquiry: A Positive revolution in change. San Fransisco: Berrett-Koehler Publishers, Inc.

Cuban, L., \& Usdan, M. (Eds.). (2003). Powerful reforms with shallow roots: Improving America's urban schools. New York, NY: Teachers College Press.

Daly, A., \& Chrispeels, J . (2005). From problem to possibility: Leadership for implementing and deepening the processes of effective schools. J ournal for Effective Schools, 4(1), 7-25.

Waters, L., \&White, M. (2015). Case study of a school wellbeing initiative: Using appreciative inquiry to support positive change. International J ournal of Wellbeing, 5(1).

Whitney, D., Trosten-Bloom, A., \& Rader, K. (2010). Appreciative leadership: Focus on what works to drive winning performance and build a thriving organization. Toronto: McGraw Hill Professional.

(C) Orr and Cleveland-Innes

\section{Athabasca University $\mathbf{Z}$}

This work is licensed under a Creative Commons Attribution 4.0 International License. 
Appreciative Leadership: Supporting Education Innovation

Orr and Cleveland-Innes

(c)

This work is licensed under a Creative Commons Attribution 4.0 International License. 